\title{
BOOK COVER INVENTORY (IN THE LATEST LITERATURE)
}

Problems related to book covers seem a potentially fruitful subject of study in the case of Polish literature created after $1989^{2}$, even more so since interest in the editions of various publications is currently increasing and undergoing specialisation. Apart from specialist approaches to design, publishing, the history of the book, and library science, bibliophile guidebooks and projects in the area of book-marketing $^{3}$, there also appear texts which strive to study cover specificity from the side of its culture-forming or aesthetic qualities, and its close relations with the art of the word ${ }^{4}$. Thus, what is being emphasised is the individual artistic form of the book

\footnotetext{
${ }^{*}$ Magdalena Lachman - Ph.D., works in the Chair of Polish Literature of the $20^{\text {th }}$ and $21^{\text {st }}$ Century at the University of Lodz. She has published on contemporary Polish literature and its connections with mass culture, media and visual culture. She is one of the coordinators of the project Literature and visual arts after 1945 run by the Museum of Modern Art in Lodz (2015-2017). She has published Gry z ,tandeta” w literaturze polskiej po 1989 roku (Playing Trash. Polish Fiction After 1989; Kraków 2004).

${ }^{1}$ A. Lindgren, Vi på Saltkråkan, trans. M. Olszańska, Nasza Księgarnia, Warsaw 1990, p. 135.

${ }^{2}$ The division indicates a change in political and cultural modes, which influenced the method of how creativity works, its material factors, and the scale and direction of receiver needs. Vide, e.g. M. Hopfinger, Literatura i media po 1989 roku, Oficyna Naukowa, Warsaw 2010.

${ }^{3}$ Vide, e.g. J. Trzynadlowski, Autor, dzieto, wydawca, 2nd edition amended, Ossolineum, Wrocław 1988, pp. 171-173; A. Biały, "Formy opraw książkowych - dotyk skórzanej okładki czy wirtualna prezentacja”, [in:] Doką zmierzamy? Ksiązka i jej czytelnik. Materiaty z II Ogólnopolskiej Konferencji Naukowej zorganizowanej przez Bibliotekę Główna Uniwersytetu Szczecińskiego, Międzyzdroje 20-22 września 2007 r., J. Gaziński (ed.), Książnica Pomorska im. St. Staszica, Szczecin 2008, pp. 188-196; P. Rypson, Nie gęsi. Polskie projektowanie graficzne 1919-1949, Wydawnictwo Karakter, Krakow 2011, passim; N. Drew, P. Sternberger, By Its Cover. Modern American Book Cover Design, Princeton Architectual Press, New York 2005.

${ }^{4}$ Vide esp. Judging a Book by Its Cover. Fans, Publishers, Designers, and the Marketing of Fiction, N. Matthews, N. Moody (eds.), Ashgate, Aldershot-Burlington, VT 2007. Cf. also J. Dunin, "Okładka i obwoluta jako komunikat. Wprowadzenie do problematyki”, [in:] Sztuka ksiązki. Historia - teoria - praktyka, M. Komza (ed.), Wydawnictwo Uniwersytetu Wrocławskiego, Wrocław 2003 [„Acta Universitatis Wratislaviensis. Bibliotekoznawstwo” XXIV (2003)], pp. 81-90 and
} 
cover $^{5}$ as well as its informative ${ }^{6}$ or often ideological or persuasive dimensions ${ }^{7}$, elevating its importance and diversifying its para-textual features ${ }^{8}$ as well as the associations the cover has with specific publishing forms and literary genres identifying the fact that it constitutes a significant identifier of convention, particularly in the case of works in popular circulation'. Even without delving into the nature of the discussion, it seems clearly necessary to study the diversely localised message carried by book covers. In Poland, one reason for such a discussion was posed by the recent book entitled Tysiac polskich oktadek (One Thousand Polish Book Covers) by Aleksandra and Daniel Mizieliński, which presented the achievements of 20th-century Polish book graphic design ${ }^{10}$. The work, an album or anthology if you will, created by graphic designers was often discussed by representatives of the

other works of the author: "Okładka i obwoluta”, [in:] Rozwój cech wydawniczych polskiej ksiązki literackiej XIX-XX wieku, Wydawnictwo Uniwersytetu Łódzkiego, Łódź 1982, pp. 120-137; “Okładka i obwoluta w procesie komunikacji literackiej”, Nowe Ksiązki, 1993 issue 1, pp. 70-71; “Okładki, obwoluty i wystawy książek w komunikacji literackiej”, [in:] Pismo zmienia świat. Czytanie. Lektura. Czytelnictwo, Wydawnictwo Naukowe PWN, Warsaw-Łódź 1998, pp. 98-105. Vide also my article: M. Lachman, "Nie(d)ocenione usługi okładki", [in:] Stolice i prowincje kultury. Ksiega Jubileuszowa ofiarowana Profesor Alinie Kowalczykowej, J. Brzozowski, M. Skrzypczyk, M. Stanisz (eds.), Wydawnictwo IBL, Warsaw 2012, pp. 566-584.

${ }^{5}$ Vide, e.g. A. Węgrzyniak, "Pomnik z czarnego marmuru. O książce Tadeusza Różewicza «Matka odchodzi»", [in:] Dzieło literackie i książk w kulturze. Studia i szkice ofiarowane profesor Renacie Ocieczek w czterdziestolecie pracy naukowej i dydaktycznej, I. Opacki (ed.) in cooperation with B. Mazurkowa, Wydawnictwo Uniwersytetu Śląskiego, Katowice 2002, pp. 511-520.

${ }^{6}$ Vide, e.g. P. L. Shillingsburg, From Gutenberg to Google. Electronic Representation of Literary Texts, Cambridge University Press, Cambridge 2006, pp. 63-65.

${ }^{7}$ Vide, e.g. E. Tierling, "Czytajmy Rodziewiczównę! O perswazyjności okładki”, [in:] Rozgrywanie światów. Formy perswazji w kulturze wspótczesnej, I. Iwasiów, J. Madejski (eds.), Wydawnictwo Uniwersytetu Szczecińskiego, Szczecin 1994, pp. 273-289.

${ }^{8}$ Vide especially: I. Loewe, "Parateksty na okładkach", [in:] Gatunki paratekstowe w komunikacji medialnej, Wydawnictwo Uniwersytetu Śląskiego, Katowice 2007, pp. 85-111. It is symptomatic that the author inserted her deliberations on the book medium in a wider context of contemporary media and (self)promotion practices. Cf. also M. Lalak, "Słowo kuszące. O perswazyjności tekstu okazjonalnego w książce literackiej”, [in:] Rozgrywanie światów, pp. 291-300.

${ }^{9}$ This was recorded in entries in Stownik literatury popularnej, T. Żabski (ed.), 2nd edition corrected and amended, Wydawnictwo Uniwersytetu Wrocławskiego, Wrocław 2006 - its first edition (Towarzystwo Przyjaciół Polonistyki Wrocławskiej, Wrocław 1997) included an annex with reprints of the covers of specific genres and publishing series. Those issues tend to reappear in articles published in the Esensja. Magazyn Kultury Popularnej journal (vide http://esensja.pl/), which presents, e.g. rankings of the best and worst covers, but also more recent publishing practices in this scope. Cf. also T. Stępień, "Tekst okładki”, [in:] Dzieło literackie i książka w kulturze, pp. 502-510; S. Brown, Magia Harry'ego Pottera. Kreaowanie globalnej marki, trans. H. Bem, Wydawnictwo Naukowe PWN, Warsaw 2008, pp. 52-53; B. Krupa, "Poetyka powieści Marka Krajewskiego", Podteksty, 2010 issue 4, accessed on: http://podteksty.amu.edu.pl/podteksty/?action=dynamic\&dzial=4\&id=158 [2012.09.30].

${ }^{10}$ Tysiac polskich okładek. One Thousand Polish Book Covers, selection by D. Mizieliński, A. Mizielińska, Stowarzyszenie 40000 Malarzy, Warsaw 2010. 
literary community ${ }^{11}$ : Krzysztof Varga emphasised enthusiastically in his column: "it is truly a book on reading, for me one of the most important books on the phenomenon of reading and collecting books in a long time," stating at the same time that: "a book cover is, for me, an integral part of a novel," and indicated how cover stimuli can determine aesthetic choices: "I like books with nice covers better, maybe not even with nice covers but surely with interesting ones." 12

Such an attitude is influenced by the domestication of the publishing principles required by the book market (the growth and expansion of the publishing capabilities in Poland since 1989 has been stimulated by the lifting of censorship, facilitated access to printing services, enhanced printing techniques, and the introduction of digital printing; all that, on the one hand, has resulted in intensifying production in popular circulation and, on the other, has led to the arrival of increasingly favoured self-publishing, acquiring momentum thanks to the internet and the ability to distribute their physical publications and e-books ${ }^{13}$ ) as well as the context of mass culture, which assigned an important place to the covers of not only books but also comic books, recordings, films, and magazines ${ }^{14}$, placed a focus on seeking increasingly more sophisticated solutions and, at the same time, introducing rules of the presence and promotion of literary output in mass media. Firm cover priorities are confirmed by the mode of utilising books in the press, television ("some publishers consult the designs of the covers so that they look good on TV"15), websites ${ }^{16}$, publishing catalogues, book stores, window displays,

${ }^{11}$ Vide, e.g. M. Baranowska, "Siła papieru”, Nowe Książki, 2011 issue 4, pp. 56-57; A. Pałys, “Oczy zaświeciły mi się z radości...”, Lampa, 2011 issue 3, p. 59.

${ }^{12}$ K. Varga, "Melancholia okładek, czyli spieszmy się zbierać książki”, Duży Format [suppl. to Gazeta Wyborcza, 2011, issue 109] 2011, issue 18, p. 19. He further enhanced his observations through yet another individual finding: "I like a CD with a nice or at least interesting cover more, the music sounds better to me."

${ }^{13}$ The cover is, in fact, also important in their case, which is visible in the multitude of websites with designs and templates of virtual books enabling you to personalise and tailor the cover of your e-book to your individual needs; you are encouraged to use such an offer with a slogan: "So you can see the influence of the right cover!" (http://ebooki.tbg.net.pl/html/covery.html [2012.10.15]).

${ }^{14}$ Vide, e.g. M. Rychlewski, "Suwaki, plakaty i inne atrakcje. Rzecz o okładkach rockowych", Kultura Popularna, 2003 issue 3, pp. 95-101 (abridged version of the text: "Suwaki, plakaty i inne atrakcje. O okładkach rockowych", Polonistyka, 2007, issue 1, pp. 45-50); A. E. Sekuła, "Okładka «Cosmopolitan»”, Kultura Wspótczesna, 2004, issue 4, pp. 11-15; J. Szyłak, “Okładki i odbiorcy. Komiks jako książka", [in:] Poetyka komiksu. Warstwa ikoniczna i językowa, słowo/obraz terytoria, Gdańsk 2000, pp. 154-173; cf. also "Polowanie na okładki i kluczowe sceny. Rozmowa z Krzysztofem Masiewiczem", [in:] S. Frąckiewicz, Wyjście z getta. Rozmowy o kulturze komiksowej w Polsce, Stowarzyszenie 40000 Malarzy, Warsaw 2012, p. 236.

${ }^{15}$ L. Mikołajczuk, "Dyskusyjne kluby książki - przenoszenie wzorów brytyjskich do polskich na przykładzie współpracy British Council i Instytutu Książki”, [in:] Dokąd zmierzamy? Książka i jej czytelnik, p. 103.

${ }^{16}$ Vide, e.g. A. Weedon, "In Real Life: Book Covers in the Internet Bookstore", [in:] Judging a Book by Its Cover, pp. 117-127. 
on posters, booths, fairs, street stalls as well as in public and home libraries. ${ }^{17}$ One could get the impression that the binding of the medium has become more important than the medium itself, according to the principle: "People might not buy books for their covers, but they sure buy books thanks to them." ${ }^{18}$ This new civilisational trend was summed up rather sarcastically by Andrzej Bart:

My friend who practices a different kind of art gave out at one biennale a page of the New York Times dated 2020. It included news reports on events which might occur in the future. However, before the viewers brought the newspapers home, the print vanished leaving a blank piece of paper. I often think to myself whether the times are coming when we will be able to sell books that way. A beautiful cover where the publisher promises that nothing as magnificent has been written since the Bible or with a neat slogan like: "I fainted reading it", and then only blank pages inside. That could be enough. ${ }^{19}$

Krzysztof Varga depicted the situation in a similarly bleak mood: "I call upon you to already start collecting book covers from the 21 st century. As long as there are still book covers and that what is in between them. Don't waste time and love books, tablets are coming." 20

Similar voices not only fit the catastrophic visions of the fall of readership or the downgrading of the book to the role of goods, the value of which depends on the attractiveness of their form and packaging. Unintentionally, they indicate both the responsiveness towards the status of the very medium of a literary work and its dependence on the form of physical recording (NB: it resonates with contemporary efforts of the plastic arts in terms of book art, e.g. the projects by Zbigniew Sałaj, the author of works in the perceiving of which touch plays a major role; the artist has utilised used wooden printing type cases to create book items "printed in

${ }^{17}$ Those issues often appear in, e.g. a series of interviews with public figures and their book collections: Ksiażki i ludzie. Rozmowy Barbary Łopieńskiej, Twój Styl, Warsaw 1998; cf. also M. Lachman, Nie(d)ocenione ustugi, pp. 568-570. The presentation convention used in must read summaries is quite emphatic. One such publication (P. Boxall, 1001 książek, które musisz przeczytać przed śmiercia, trans. M. Balas et al., Elipsa - Publicat, Poznań 2008) is recommended in the following manner: "It is a unique opportunity for bibliophiles to view over 600 colour covers and frontispieces, and other illustration material associated with specific titles" (http://lubimyczytac.pl/ ksiazka/62613/1001-ksiazek-ktore-musisz-przeczytac; [2012.10.01]).

${ }^{18}$ S. Brown, Magia Harry'ego Pottera, p. 52. Cf. also D. Ugrešić, Czytanie wzbronione, trans. D. J. Cirlić, Świat Literacki, Izabelin 2004, passim.

19 "Uśmiech - inteligencka przywara. Z Andrzejem Bartem rozmawia Tadeusz Sobolewski", Duży Format [suppl. to Gazeta Wyborcza] 2009, issue 44, p. 21.

${ }^{20} \mathrm{~K}$. Varga, Melancholia okładek, p. 19. However, experience shows that even tablets have access to electronic versions of book covers which are designed in a manner imitating the physical book medium (on this matter vide A. Biały, Formy opraw ksiażkowych, pp. 193-194). Furthermore, "the rise of a new medium not only does not kill the previous one but always releases it from some or other easements" (U. Eco, Nowe środki masowego przekazu a przyszłość ksiązki, trans. A. Szymanowski, PIW, Warsaw 1996, p. 15). Vide, also P. L. Shillingsburg, From Gutenberg to Google. 
such a way that the more you read the text, the sooner it will disappear"). ${ }^{21}$ There emerged a peculiar relation: the more inventions and capabilities of overcoming the limitations of the physical book medium there are, the greater attention is attached to its standard attributes and the more the book cover seems a generator of specific meaning for the literary medium.

The matter expands far beyond the issue of standardising the layout of publishing series which promote the latest Polish literature (something in which such publishing houses as Wydawnictwo Czarne, Wydawnictwo W.A.B., and Korporacja Ha!art specialise) or the general problem of the applicability of the book cover (usually in terms of a visual equivalent of the work) to the meaning evoked by a given work ${ }^{22}$. In the case of the latest literature, the book cover has often become a purposeful subject of creative activities which apply to all its components, such as the visual form, typography, the format, the dust jacket, the mode of emphasising the title or the publisher, sometimes patrons of the arts or media partners, information about the author (inscription of her/his name, bio, photographs... ${ }^{23}$ ), any prières d'inserér ("invitation to the inside") ${ }^{24}$, or the special form known as blurbs (commissioned and calculated for a marketing effect, laconic recommendations in the form of enthusiastic invitations or positive micro-reviews created solely for the cover of a book, a music record or a film) ${ }^{25}$ To ensure the coherence of their message, creators also strive to assign the editorial components of the works with tasks enhancing the entire work and to protect them from the provisions of publishing convention which is external in reference to the text (or: subject them to the provisions according to individually established rules). This aspect resonates in the discussion of Sławomir Shuty's Betkot:

The pink Harlequinesque cover, indicators specifying the intensity of action, violence and sex in the text, a drawing of the alleged steroid-chugging author and a very promising incentive

${ }^{21}$ M. Pisarski, "Kartografowie i kompilatorzy. Pół żartem pół serio o praktyce i teorii hiperfikcji w Polsce", [in:] Literatura polska 1989-2009. Przewodnik, P. Marecki (ed.), Korporacja Ha!art, Krakow 2010, p. 280. Significantly, the example becomes the context for discussing the technical requirements and experiment-based form of the latest literature.

${ }^{22}$ This issue is also raised by critics - cf., e.g. the remark on Glowa wroga by Augustyn Baran or other publishing projects of Wydawnictwo Czarne: "The cover designed by Kamil Targosz merging two examples of kitsch aesthetics, i.e. the fake folk papercutting art and pseudo-African primitive art (there was a time when in Cepelia folk shops you could buy quasi-African masks made of gypsum), perfectly summarises the nature of the prose (the graphic designs in Dukla by Stasiuk similar in their aesthetics were a complete mismatch)" (K. Uniłowski, "Smak literatury, smak kiełbasy", [in:] Koloniści i koczownicy. O najnowszej prozie i krytyce literackiej, Universitas, Krakow 2002, p. 59).

${ }^{23}$ Vide, e.g. D. Ugrešić, Czytanie wzbronione, i.a. pp. 63-64.

${ }^{24}$ On this topic, vide a detailed typology in I. Loewe, Parateksty na okladkach, pp. 85-111.

${ }^{25}$ Vide, e.g. D. Ugrešić, Czytanie wzbronione, pp. 7-8, 57-60; A. Wolny-Hamkało, Zrób mi dobrze, czyli krótki tekst o pisaniu blurbów, http://www.biuroliterackie.pl/przystan/czytaj.php?site $=260 \&$ co=txt_1344 [2012.09.30]; J. A. Urbanowicz, "Okładki: blurb, blurb", Esensja 2001 issue 7 (accessed on-line: http://www.esensja.pl/magazyn/2001/07/iso/13_23.html [2012.09.30]). 
("Check this out! 100 PLN inside") matched the atmosphere of the foul world presented in the work. It is not often that on the cover of a book one sees a facial with cucumbers, which would perfectly supplement all more or less bearable visual and cooking comments made by Shuty's character(s). The fact of using such means does not resemble, in this case, a marketing strategy. The intention is not for the book to "be just nice" (as it is not intended to be nice) but to "be catchy". The distinctive, when compared with other similar items published within the Kolekcja "Ha!art" collection, finish of the cover is an attempted statement on [...] reality but mainly it is an attempt to make a statement in a specific way, an attempt to find a new language ${ }^{26}$.

The conclusions do not even need to be so far-reaching for one to notice the role of a book's exterior as a medium of a writer's ideas and a significant component of literary life after 1989. Within its framework, the issue of the book cover has had various manifestations revealing several properties.

Firstly, what is significant today is not only the method of accumulating cover meanings but also the rules of decoding them. The commentators of the latest literature are convinced that the author has a significant influence on the form of the cover, if not actively (co-)creating it, then at least accepting the design. The openness to deciphering itself is the reason why the meanings assumed by the book cover constitute a starting point for discussions aimed at grasping the programmed intentions of specific messages, e.g. this is applied to the "pastiche design" of a book by Dariusz Bugalski entitled 83 piosenki które pomoga ci dociagnąc do czterdziestki:

Its graphic design was a parody of the cover of one of the best-known records in the history of popular music - Sgt. Pepper's Lonely Hearts Club Band by The Beatles. It included an additional advertising strip which promised: "62 performers 8 hours of music" (the figures probably alluded to the number of character-musicians in the book or alternatively - could signify the total length of the songs referred to in the book or the time needed to read it). The form of the title - 83 piosenki które pomoga ci dociagnać do czterdziestki [...] - suggested that the reader will read a personal witty guidebook to music hits written by a radio celebrity. The suggestion was amplified by the patronage of Polish Radio Three, the recommendations by Marek Niedźwiecki, a music journalist and one of its pillars, and Krystyna Kofta, a popular writer and author of books parodying the forms of guidebooks and manuals (e.g. Jak zdobyć, utrzymać i porzucić mężczyznę and Wychowanie seksualne dla klasy wyższej, średniej i niższej). [...]. When you look closely at the graphic components of the cover with the musical characters of the book, you will find, absent in the Beatles original, images of popular animals: a fox, a cock, a deer, and Godzilla. The author and the clever publisher would be the Cunning Fox, while the readers would obviously be the deer (in Polish having a similar meaning to the ass). [...] The fox and the cock resemble the main characters of one-act plays by Sławomir Mrożek - embodying the archetypes of an artist and a philistine, the complex nature of their mutual relations in the contemporary world. ${ }^{27}$

${ }^{26} \mathrm{~W}$. Rusinek, "W poszukiwaniu utraconej rzeczywistości. Jeszcze raz o prozie tzw. «roczników siedemdziesiątych»", [in:] Literatura polska 1989-2009. Przewodnik, p. 98. The release of Jaszczur, the latest novel by the author of Betkot, was preceded by the following announcement: "Sławomir Shuty knocks out of our hands all the worn-out interpretative tools which look so nice in publishing blurbs" (Ha!art, 2012, issue 38, p. 93).

${ }^{27}$ M. Rabizo-Birek, "Piosenki prozą - o narodzinach nowego gatunku?", [in:] Dwadzieścia lat literatury polskiej 1989-2009, vol. 1, part II: Życie literackie po 1989 roku, D. Nowacki, K. Uniłowski (eds.), Wydawnictwo Uniwersytetu Śląskiego, Katowice 2011, pp. 211-212. 
In such explications, the book cover functions as a primary signal of text-evoked rules of imaging and information on the scope and subject of potential tensions between the author/sender and the recipient. In many reviews, essays, and literary critical discussions, the bookbinding is not only noticed and subject to discussion, but the very start of the argument is organised around its characteristics, which even results in creating specific cover-based ekphrases or micro-narratives (they often appear in texts which usually include the front covers of books, as if just one look at a cover was not enough or it immediately required a precise verbal definition ${ }^{28}$ ).

Secondly, it is typical for the specified problem area to combine contradictions: contemporary covers depict the (im)possibility of determinational appropriations included in the text and its (un-)openness to various modes of reading. They can determine the message strongly by limiting the interpretative pliability, at the same time signalling its openness, including its hybrid or "hypertextual" structure or unwillingness to stabilisation in the orthodox form (the fact that the book façade is suited for illustrating such operations was proven by the example of Matz by Marta Dzido, a novel equipped by the publisher with two cover variants differing in terms of the colour of clothing accessories of the featured figure of a woman, pessimistic or optimistic, depending on the given version of the ending).

Thirdly, the rise in the importance of the book cover is accompanied by, paradoxically, the increasingly significant distribution of literary works outside of the physical medium (e.g. on the internet, urban space, in the form of audiobooks, in a performance or happening setting, or in the oral form, confirmed, e.g. by the case of slam competitions) or deconstructing its idea (e.g. in celebration of the 15th anniversary of the Topos bimonthly, a unique anthology entitled Wiersze wystane (Sent Poems) was published; it was a paper case, resembling a package of stationery, which consisted of thirty poetic postcards ready for circulation via mail, each with a poem and a photograph of its author ${ }^{29}$ ). The focus on the covers as well as the increasingly popular "coverless" practices have a common determiner: in both cases, the goal is to eliminate or modify the conventional intermediaries

\footnotetext{
${ }^{28}$ Cf., e.g. a review of a book by A. Tuszyńska entitled Tyrmandowie: A. Rybak, "Tyrmand w kapciach", Rzeczpospolita [suppl. Rzecz o Książkach] 2012, issue 210, p. P17.

${ }^{29}$ Wiersze wystane, T. Dąbrowski (concept, series editor and photographs), graphic design by P. Dębowski, Topos, Sopot 2008. The idea to publish books in that form is not new, e.g. a novel by B.S. Johnson entitled The Unfortunates (Polish edition: Nieszczęśni, trans. K. Bazarnik, Korporacja Ha!art, Krakow 2008) was published in 1969 in the form of loose sheets in a cardboard box. An attempt at altering the editorial form in the Hungarian translation published in a traditional bound volume deprived the readers of sensual and emotional experiences and resulted in a loss of the work's semantics: "The material form of The Unfortunates resembles the gesture of a person spreading her/his arms helplessly. What other words could reflect what one feels when her/his loved ones pass away? [...] the reader, when placing in a small box the remains of «the Unfortunates», [...] feels like the narrator accompanying her/his friend in their last journey" (K. Bazarnik, "Liberatura: ikoniczne oka-leczenie literatury", [in:] Tekst-tura. Wokót nowych form tekstu literackiego i tekstu jako dzieła sztuki, M. Dawidek Gryglicka (ed.), Korporacja Ha!art, Krakow, p. 31).
} 
in the contact with the recipient. Writers who employ such strategies do not wish to enclose or bind their projects in standard media forms, seeking alternative methods of communicating meanings characteristic of the art of the word. Thus, the issue of (in)significance or use(lessness) of the book cover becomes ambiguous, which is visible in the proposal formulated based on the concept of liberature (the name, which is a blend of the words "literature" and the Latin liber - as a noun meaning "a book" or "a writing" and as an adjective meaning "free" or "independent" - is applied by Zenon Fajfer, its proponent, and Katarzyna Bazarnik to literary projects which treat the physical medium of a text as an integral element of the message):

Therefore, should not the shape of the cover (if the cover must be present at all), the type of paper (or other material), the shape and direction of the writing, the format, the colour and the number of pages, words, or even letters be the object of consideration of the creator just like any other element of the work, requiring from her/him just as much attention as the selection of rhymes or constructing the story? ${ }^{30}$.

Finally, in the case of the latest works, functions usually fulfilled by the cover - identifying, informative, interpretative and directing the reception, marketing, persuasive... ${ }^{31}$ - become accumulated and amplified. Additionally, the book cover assumes other tasks: it strongly accentuates its world-view and interactive or even intertextual dimensions. Furthermore, it becomes a carrier of knowledge on the cultural trends documenting, e.g. the need to intensify the experience which engage various senses when coming into contact with literature, i.e. it shows that what is important today are visual and audio stimuli (hence the practice of equipping books with CDs glued to the inside cover, or the trend to parody the covers of well-known records or use for the same purpose film shots) or even tactile (e.g. a book by Katarzyna Bazarnik and Zenon Fajfer entitled $(O)$ patrzenie was published with an intentionally torn corner of the cover which was supposed to give it an individual character - thus, the chance that there would be two identical copies of the work was successfully eliminated - but, at the same time, create a sensation of establishing physical contact with the authors). Being an inherent component of a work, the book cover also gathers the characteristic features of

${ }^{30}$ Z. Fajfer, "Liberatura, czyli literatura totalna. Aneks do «Aneksu do Słownika terminów literackich»”, [in:] Liberatura czyli literatura totalna. Teksty zebrane z lat 1999-2009, K. Bazarnik (ed.), introduction W. Kalaga, Korporacja Ha! art, Krakow 2010, p. 33 (emphasis mine - M.L.).

${ }^{31}$ A detailed typology of the functions of the book cover, though focussing on its more technical and editorial aspects, cf. H. F. Kroehl, Buch und Umschlag im Test, Harenberg, Dortmund 1984. The work is referenced in: J. Dunin, Oktadka i obwoluta jako komunikat. Wprowadzenie do problematyki, pp. 84-87 (however, the article quotes the name of the German researcher erroneously). The findings only partially influenced my study. Much closer to me is the focus on literary works proposed by D. Danek, Dzieło literackie jako książka. O tytułach $i$ spisach rzeczy w powieści, PWN, Warsaw 1980 (even though the researcher did not focus on the book cover as such, some of her remarks seem to possess a wider application). 
contemporary literary life, in particular it reflects the need to seek out points of reference within the audio-visual and media space, as well as the tendency to work closely with the representatives of various artistic communities, e.g. the cover for Betkot was designed by Marcin Maciejowski, while the similarly mocking cover of the first volume of the collection of stories by Sławomir Shuty entitled Cukier w normie was created in cooperation with Wilhelm Sasnal. Even "the idea to support literature with graphic design of the contemporary generation" 32 is reflected in the covers of compendiums, guidebooks, and anthologies aiming for the trademark of a generation manifesto (e.g. the covers of the collections entitled Tekstylia. O „rocznikach siedemdziesiatych” and Tekstylia bis. Słownik młodej polskiej kultury wykonał were developed by Wilhelm Sasnal, while the covers compiled by Roman Pawłowski for the anthologies of the latest Polish plays entitled Pokolenie porno i inne niesmaczne utwory teatralne and Made in Poland. Dziewięć sztuk teatralnych z Polski included replicas of paintings by Marcin Maciejowski: Apolonia i Michael Corleone 2003 and Granice glupoty respectively; the graphic design of the interdisciplinary project book entitled Warszawa. W poszukiwaniu centrum. Miejski przewodnik was developed by the Twożywo collective, while the trademark of the Lampa journal from its very beginning has been its cover - consistently instead of photographs presenting drawn versions of writers' portraits, which mockingly alluded to the publishing conventions of pop magazines and the so-called coloured press - created by Agata Nowicka, a well-known graphic designer and creator of comic books, better known as Endo). It is symptomatic that along with the emerging desire in such projects to fit the general atmosphere of the latest literature and to legitimise its dominating features, comes the need to manifest these attitudes already at the basic layout level. It is, in fact, telling that the covers created in artistic cooperation function at the same time within the worlds of literature and the visual arts, mutually enhancing their messages. A similar goal is set before the graphic design of Dorota Masłowska's books, particularly those which were given their unique typographic shape by Maciej Sieńczyk:

The square format of Paw... was proposed by the writer, the publisher suggested the Art Nouveau style of the cover. The cover was supposed to include a bicycle and Dorota Masłowska in a crown. [...] The cover of Paw... includes two colours, trademark colours of Art Nouveau: copper red and olive green. The square at the turn of the 20th century continued to appear in furniture decorations and architecture. However, it is also a low-grade phenomenon - it is the format of children's books in cardboard covers. And the format of music records. The combination of the high and low grades resulted in the creation of the most fin-de-siecle and decadent contemporary Polish book. ${ }^{33}$

An important element of the cover of Paw królowej was also the inclusion on the back of a close-up portrait of the author with her tongue sticking out, touching an

${ }^{32}$ D. Jarecka, “Obraz rozpisany na kartkach”, Gazeta Wyborcza, 2005, issue 149, p. 16.

${ }^{33}$ D. Jarecka, Obraz rozpisany na kartkach, p. 16. 
opened jar of beetroot horseradish relish bearing a label with the caption: "POLAND BURAKI przetarte" (grated POLAND BEETS), where - apart from the obvious play on words ${ }^{34}$ - one might find an ironic approach to the indispensable, in the case of the latest literature, requirement for media adequacy and "photogenic" character ${ }^{35}$.

Many writers (in addition to those already mentioned, Manuela Gretkowska, Darek Foks, Jaś Kapela, or the writers promoted by Paweł Dunin-Wąsowicz, owner of the Lampa i Iskra Boża publishing house, excelling at mock anti-recommendations ${ }^{36}$, reversing the rules of today's expansive blurbs) would like to define themselves through their book covers and owing to their choices their readers expect ever more often that book covers include something worth considering when reading and interpreting the books (they have clearly confirmed during interviews, self-commentaries, and meet the author sessions their attachment to the layouts of their books). In the case of such propositions, the effect of focussing attention on oneself becomes further amplified by the fact that there exists a dialogue between renewed editions or consecutive books of a given author, a matter well depicted by the new editions of Wojna polsko-ruska pod flaga biato-czerwona (Snow White and Russian Red) by Dorota Masłowska:

in the 1st edition of Wojna polsko-ruska [...], the cover was developed by Krzysztof Ostrowski, lead singer and lyricist of the band C.K.O.D. Ostrowski made colour illustrations to the 2nd edition. However, what Maciej Sieńczyk did in the latest edition are not just an interesting cover and illustrations. [...] Ostrowski illustrated the literature of a rebelling teenager. Sieńczyk's cover and drawings placed irony on that rebellion. There is a Bolshevik in a fur hat drawing his sabre to cut a Polish woman in half, the medic in the foreground offers the wounded a narcotic. Art Deco-style letters and characters as if taken from a propaganda poster from the Polish-Bolshevik war create an absurd combination. ${ }^{37}$

Such activities do not necessarily seem an exchange of opinions on the emergent message of the work. They are rather a play on access codes to the work; new versions of the cover are rather contiguous, not disjunctive. As easy as it is to use

${ }^{34}$ It corresponds to a cover of an issue of an Olsztyn-based Portret journal (2001/2002 issue 12) which included a negative of a photograph of the journal's editors with the Palace of Culture and Science in the background and a caption: "Buraki w warszawce" (hillbillies in Warsaw). The editors used as the main slogan of the issue the phrase: "It doesn't matter how you write, what is important is how you strike a pose, you ape".

${ }^{35}$ More on the subject, vide D. Różycka, "Autorzy i ich maski. O fotografiach pisarzy współczesnych”, [in:] Teatr wielki, mniejszy i codzienny, P. Kowalski (ed.), Wydawnictwo Uniwersytetu Opolskiego, Opole 2002, pp. 211-230. Cf. also D. Ugrešić, Czytanie wzbronione, pp. 61-64.

${ }^{36}$ I quote the examples in other locations - vide M. Lachman: Gry z „,tandeta” w prozie polskiej po 1989 roku, Universitas, Krakow 2004, pp. 359-360 and "Mania wydawania, czyli o fenomenie «Lampy i Iskry Bożej»”, [in:] ,,Czarne” oraz „Lampa i Iskra Boża”. Literatura na rynku idei, D. Kalinowski (ed.), Akademia Pomorska w Słupsku, Słupsk 2010, pp. 112-117.

${ }^{37}$ D. Jarecka, Obraz rozpisany na kartkach, p. 16. The triad can be further supplemented with the film cover of the new edition of Wojna polsko-ruska... released in 2009 celebrating the film adaptation of the novel by Xawery Żuławski. 
them to programme the reception or enforce a specific vision of a work, in this case they are more about controlling the reader, even if only to seize and keep her/ his attention.

The receiver well-accustomed to the rules of artistic life since 1989 is now required to know both strictly literary as well as... editing facts. Thus she/he must consider not only what is present on book covers, but also what is played out between them, within the intertextual references and interactional assumptions (they similarly apply to visual elements, typographic components and verbal factors, and they are manifested through references to both, specific books and non-literary forms). Such a strategy is visible in the publications of the Lampa i Iskra Boża publishing house, e.g. in consecutive editions of Parnas bis. Stownik literatury polskiej urodzonej po 1960 roku (e.g. the caption: "This is not the first Polish post-modern novel!" located on the last page of the cover of the 1st edition of the quasi-encyclopaedia, which engaged in a game with the convention of a dictionary, was amplified in the 3rd edition of Parnas bis where in the same place there was a bold statement by the editors: "The last Polish post-modern novel!") or an anthology entitled Macie swoich poetów (in its renewed edition on the back cover there was a note to the reader: "Look closely and compare it to the 1st edition to find 7 differences in the table", while the front cover of the 2nd edition of the book presented inside a bright green circle a visible lure associated to the trade and consumption lexicon and maintaining the character of practices straight out of a supermarket flyer: " $20 \%$ more" with a smaller-case note "poems in new packaging", which was an ironic gesture exposing the trade aspect of the message and concisely indicated the context of the functioning of literature under pressure from trade and marketing requirements). The patronage of Lampa and Iskra Boża enabled the reactivation of the famous purple bruLion series, within which in 1993 (antedated to 1992) there appeared simultaneously seven collections of poems by various poets, offering a hallmark illustration of the magazine's strategy and features of the literature it promoted. The graphic trademark of the collective edition were the covers of individual collections maintained in the same colour with a horizontal logo of bruLion in the bottom right-hand corner, each time without the title or the author's name, featuring only a part of a photograph of her/ his face. In 2002, Paweł Dunin-Wąsowicz referred to the project by publishing seven collections of poetry with graphic design by Marcin Maciejowski, who placed portraits of the authors of a given collection on violet and white covers ${ }^{38}$, but the status of a classical renewed edition was only assigned to the collections Zimne kraje by Marcin Świetlicki and Ciamkowatość życia by Grzegorz Wróblewski. The group of indicated writers included another bruLion author, i.e. MLB (Miłosz

\footnotetext{
${ }^{38}$ With the exception of Miłosz Biedrzycki, who supposedly did not agree to such a variant of his portrait (the information was provided by Bartosz Muszyński during his evening poetry reading session in Słupsk on 4 December 2008).
} 
Biedrzycki), but with a new collection of poems. The remaining collections were authored by other poets selected subjectively by the publisher: Bartosz Muszyński, Michał Kaczyński, Jan Riesenkampf, and Wojciech Wilczyk. That editorial device enabled the owner of Lampa i Iskra Boża to verify after several years the output of authors who stormed Polish literature after 1989 and indicate the continuity of generational experiences, the still applicable artistic patronage, and the topicality of specific poetic dictions.

It is symptomatic that the formula of collective presentations weighing on the poetical series under the patronage of bruLion (apart from the purple series, there were also the white, the multi-coloured and the not completely fulfilled horizontal series) as well as other publishing initiatives ${ }^{39}$ emerging within the community of that important body of young writers was supported by the editorial form of published books, including the appearance of their covers. The cover strategy of the journal itself was also telling, which was reflected in the manner in which its achievements and heritage were discussed ${ }^{40}$. The editors at bruLion (as well as other special-focus journals and magazines such as Ha!art, Portret, Meble, Rita Baum, Fronda, Lampa (before it Lampa i Iskra Boża) and other proposals of the art magazine nature or pedigree) observed the rule which stated that all the components of a message, even the most conventional ones, can be assigned tasks appropriate to the declared needs, e.g. using typography, it is easy to define the hierarchy of the elements in a text and strike an accord with the reader as well as clarify various cases of dissonance occurring in art communication. Sometimes, specific editorial decisions are so easily identifiable that they become a quotation reference, e.g. the format and the appearance of the cover of bruLion published in two issues: 19A and 19B was referenced independently by issue 19 of the Krakow-based Ha!art (also published in two volumes) and the Olsztyn-based Portret

\footnotetext{
${ }^{39}$ Vide also anthology: b.g. wstajmfśke, przyszli barbarzyńcy, Oficyna Literacka, Krakow 1991.

${ }^{40}$ Vide M. Wieczorek, ,,bruLion”. Instrukcja obstugi, Korporacja Ha!art, Krakow 2005 (the publication included an index with photographs of earlier covers of all issues of the periodical). Vide also A. Horubała, "bruLionu przygoda z wolnością", [in:] Marzenie o chuliganie, Biblioteka „Debaty”, Warsaw 1999, p. 128. The legends surrounding the cover of bruLion are inaccuracy-ridden, which even further emphasises the importance of the cover in the reception of a periodical - cf., e.g. a fragment of the interview: Stowa narastaja powoli. Rozmowa z Jerzym Jarniewiczem, interviewed by M. Bomanowska, P. Wesołowski, Gazeta Lódzka [insert in Gazeta Wyborcza] 02.10 .2003 , p. 6 :

Literatura na Świecie of 1995. On the cover, the names in capital letters: Barańczak, Jarniewicz, Kubiak, Kuryluk. And in tiny font: Dante, Borges et al. A few months prior, the underground bruLion at that time also included capitalised names of Sendecki and Świetlicki, and the names of Mickiewicz and Miłosz in small font. That was a conscious copying of the provocation?

- In Literatura, the idea was quite different. The capitalised names were the names of translators. That was a statement [...] of the journal's policy, its profile. The aim was to remind the readers of the important role of the translator in receiving foreign-language literature.
} 
(inside, it included a glued in novel by Tomasz Białkowski entitled Dhużyzny, which deprived its cover of an exposed position).

Inter-cover dialogues can also be approached diachronically, seeking comparison for them in literary traditions. Then, the association with the methods employed by avant-garde artists who observed the principle of artistic cooperation and emphasised that "the main value of a book is its format and print, and only then the content. Which is why a poet ought to be the typesetter and the binder of his/her books" ${ }^{41}$ becomes clear. By demonstrating their strong and not always conscious dependency on the ideas formed by their predecessors, writers prove the timeliness and the aesthetic consequences of long-formulated stipulations.

The publishing convention for books and magazines/journals exemplifies the current leading cultural and artistic trends, and the desire to distance oneself from them quickly, which in turn becomes the theme of some of the works. They mock all cultural fads and expressions of snobism, e.g. in the reality of the world presented in the latest novel by Dorota Masłowska, it is easy to buy in a supermarket "a rubber cover of Sejm Sermons by Piotr Skarga [...]. Crazy gadget if you ask me - you can put it on any book" ${ }^{\prime 2}$ and pretend you possess erudition. The contemporary hegemony of the book cover was even caricatured in a community satire entitled Katecheci i Frustraci allegedly by Marianna G. Świeduchowska (a nom de plume of Marcin Świetlicki and Marcin Dyduch jointly).

The woman exploited the little shit and the little shit let her exploit him.

On the nightstand, on the covers there were nine small books with the eyes of nine poets. The little shit came up with another bright idea. His youthful perverse imagination gave him the idea at the right moment.

He moved a bit towards the nightstand and reached out.

On top, there was a book by Owietrz. The little shit covered his face with it and made frivolous motions along the rhythm of Owietrz's poems.

After some time, he turned into Świecki glancing gloomily from the cover and fornicated with the Woman gloomily.

He then turned into Roman Fasolka Bretoński and everything became plain and coarse, though the little shit thought it pure metaphysics.

For a moment, he became himself, the little shit, as the next book, one by the poet Cyrkiel, fell on the floor.

He became Starosądecki. Epiphany works well with women, so it did work on these as well. So he decided to be Starosądecki the longest.

Only when the woman's face began to show some weariness, did he reach for the next collection, this time about Krzyś O'Hara - a bit of America in post-PRL.

Next the epic poet Przesadło. It was epic and verbose.

${ }^{41}$ A. Stern, A. Wat, "Prymitywiście do narodów świata i do Polski”, [in:] Antologia polskiego futuryzmu i Nowej Sztuki, introduction and commentary Z. Jarosiński, selection and preparation of texts H. Zaworska, Ossolineum, Wrocław 1978, p. 6. Vide also P. Rypson, Ksiażki i Strony. Polska ksiązka awangardowa i artystyczna w XX wieku, CSW, Warsaw 2000; idem, Nie gęsi, pp. 26-69, pp. 318-331.

42 D. Masłowska, Kochanie, zabiłam nasze koty, Noir Sur Blanc, Warsaw 2012, p. 104. 
The woman reddened where ladies usually blush.

The little shit had reddened at the very beginning so now he started turning pale for a change.

For a short while he was a proud Viking commanding his ship to his home fjord. The ship bore the spoils: valuables covered in the blood of his victims of both sexes. The collection of the poet Wróblewski shut itself.

And finally, Sylfas.

The initiated know what the cover of Sylfas's poetic collection features.

I refer the rest to the school library.

Full of themselves and relaxed, they lied. The little shit decided it was high time to say something.

The woman felt like the history of literature, while the little shit as nothing less than the chairman of SPP.

Did you score them?

Who?

Well, those... Those from the covers ${ }^{43}$.

In that vision, the coming into contact with a literary message amounted to coming into contact with the book cover through which it appeared while the reading was replaced by the consumption of the text, something which is, in fact, encouraged by its form. The writers construct their works not only to set a trap for the reader by creating lures (literal or à rebours) for them, but at the same time they follow the rule stating that what disappears is first the book and its contents, and only then the packaging.

The cover seems today such an attractive medium of communication because it enables more extensive control over the message, various deceptions ${ }^{44}$, and meets the aesthetic and perceptive needs of the reader. The writer considers the fact that she/he morphs between a viewer, consumer and fan, she/he participates in culture with all its advantages (and burden), that she/he moves not just within a space with a verbal-centric focus reserved for the art of the word; that she/he may not wish to satisfy her/his want for popular and comedy entertainment, but that within her/his fancy there also is the campy wink ${ }^{45}$.

${ }^{43}$ M. G. Świeduchowska, Katecheci i Frustraci, Wydawnictwo Literackie, Krakow 2001, pp. 155-157. The quoted fragment alluded to writers who published their poetic collections in the bruLion poetic series (as they are referred to in the text: Marcin Baran, Marcin Świetlicki, Dariusz Brzóska-Brzóskiewicz, Jakub Ekier, Marcin Sendecki, Krzysztof Koehler, Jacek Podsiadło, Grzegorz Wróblewski, Paweł Filas).

${ }^{44}$ Their contemporary nature is perfectly defined by an uncredited novel entitled Wieloryb. Wypisy źródlowe (Tower Press, Gdańsk 1998), in which "we are dealing with not as much deception per se, but rather a make-believe deception, pretending" (K. Uniłowski, "Sztuka cytatu: od powieści przez anty-powieść do metapowieści", [in:] Genologia dzisiaj, W. Bolecki, I. Opacki, IBL, Warsaw 2000, p. 186; author's emphasis). It is symptomatic that the task with which the text was burdened (by its author, Jerzy Limon, who was quickly identified by the reviewers) supported "the false assignment of the work, deception on the cover and title pages." (ibid.)

${ }^{45}$ The covers are, in fact, treated as one of the markers of camp - vide A. Mizerka, "O publicznym wizerunku Manueli Gretkowskiej i estetyce kampu”, Podteksty 2006 issue 1; accessed on-line: http://podteksty.amu.edu.pl/podteksty/?action=dynamic\&nr=4\&dzial=4\&id=109 [2012.09.30]. 
"The graphic uniformity of the verbal information and the visual symbolism" ${ }^{46}$ are now considered an undeniable asset. Thus, it can easily simultaneously fulfil the roles of: a poster, and a manifesto, transcending the ludic variant of the game with the reader as a manipulated object of the writer's activities. Just like a poster, the goal of the cover is to ensure rapid communication, clarity of the message, strong identifiability, and reference. The writer can use it to present as much as possible of herself/himself and her/his message, indicate the source of her/his inspiration, artistic or generational associations, the traditions of a specific type of imaging or distance herself/himself from it, and, at the same time, she/he can easily formulate or amplify its world-view or aesthetic $\mathrm{credo}^{47}$.

As a result of the change of the operating context of Polish literature after 1989, writers today create their texts with a strong awareness of the significance of their whole environment, which they believe their works require. That is one of the reasons why the set of the main notions used for defining the literary output of the most recent decades also includes the "book's editorial development" The nature of contemporary artistic life requires the inclusion in literary science consideration of new or not completely used up thematic areas. One of the notions worth raising, which increasingly absorbs the attention of commentators, is the issue of the book cover considered as a significant element of the work and its non-neutral identifier.

The interest in the cover lies with edition science, the sociology of literary life, the study of literary communication, and the conditions of artistic life as well as semiotics, comparative studies (both traditional and inter-disciplinary), the theory and history of reception, and even translation studies. At the same time, the cover seems an interdisciplinary object of study enabling researchers to combine various aesthetic, sociological, historical, and cultural or media study perspectives. Similarly promising to the inter and trans-disciplinary approaches is the ability to locate "cover studies" within the area of cultural history and literary theory. That would require the researchers to indicate what type of a source of knowledge on the work and the general markers of literariness as works of culture book covers have become, how they exist in the historically determined receptive awareness, and, finally, how, because of them, literature confronts with the non-verbalcentric methods of communication and how it operates within a space marked by other media and arts subject to the influence of celebrity-focussed pop culture.

${ }^{46}$ J. Dunin, Oktadka i obwoluta w procesie komunikacji literackiej, p. 71.

${ }^{47}$ Cf., e.g. an interview "Niech się stanie sztuczność. Z Izabelą Filipiak rozmawia Agnieszka Kosińska", Dekada Literacka, 1995, issue 4, p. 3, 11-12. Vide also the comments on the cover of the début novel by J. Bator entitled Kobieta: E. Domańska, “Autofikcja Joanny Bator”, Teksty Drugie, 2003, issue 2/3, pp. 336-337.

${ }^{48}$ W. Rusinek, W poszukiwaniu utraconej rzeczywistości, p. 98. 
This article was published in Polish:

Magdalena Lachman, Okładkowy stan posiadania (w literaturze najnowszej), „Teksty Drugie” 2012, issue 6, pp. 101-107.

\section{Bibliography}

Baranowska Małgorzata, Siła papieru, „Nowe Książki” 2011, issue 4, pp. 56-57.

Biały Agnieszka, Formy opraw ksiażkowych - dotyk skórzanej okładki czy wirtualna prezentacja, [in:] Dokąd zmierzamy? Książka i jej czytelnik. Materiaty z II Ogólnopolskiej Konferencji Naukowej zorganizowanej przez Bibliotekę Gtówna Uniwersytetu Szczecińskiego, Międzyzdroje 20-22 września 2007 r., ed. Radosław Gaziński, Książnica Pomorska im. St. Staszica, Szczecin 2008, pp. 188-196.

Brown Stephen, Magia Harry' ego Pottera. Kreowanie globalnej marki, trans. Hanna Bem, Wydawnictwo Naukowe PWN, Warszawa 2008.

Consuming Books. The marketing and Consumption of Literature, ed. Stephen Brown, Routledge, London-New York 2006.

Danek Danuta, Dzieło literackie jako książka. O tytułach i spisach rzeczy w powieści, PWN, Warszawa 1980.

Darska Bernadetta, Reklamować czy polecać? O towarze jakim jest literatura, [in:] Dwadzieścia lat literatury polskiej 1989-2009, vol. 1, part 2: Życie literackie po roku 1989, ed. Dariusz Nowacki, Krzysztof Uniłowski, Wydawnictwo Uniwersytetu Śląskiego, Katowice 2011, pp. 13-26.

Dokąd zmierzamy? Książka i jej czytelnik. Materiały z II Ogólnopolskiej Konferencji Naukowej zorganizowanej przez Bibliotekę Główna Uniwersytetu Szczecińskiego, Międzyzdroje 20-22 września 2007 r., ed. Radosław Gaziński, Książnica Pomorska im. St. Staszica, Szczecin 2008.

Domańska Ewa, Autofikcja Joanny Bator, „Teksty Drugie” 2003, issue 2/3, pp. 336-345.

Drew Ned, Sternberger Paul, By Its Cover. Modern American Book Cover Design, Princeton Architectual Press, New York 2005.

Dunin Janusz, Okładka i obwoluta, [in:] Rozwój cech wydawniczych polskiej ksiażki literackiej XIXXX wieku, Wydawnictwo Uniwersytetu Łódzkiego, Łódź 1982, pp. 120-137.

Dunin Janusz, Okładka i obwoluta jako komunikat. Wprowadzenie do problematyki, [in:] Sztuka ksiązki. Historia - teoria - praktyka, ed. Małgorzata Komza, Wydawnictwo Uniwersytetu Wrocławskiego, Wrocław 2003 [„Acta Universitatis Wratislaviensis. Bibliotekoznawstwo” XXIV (2003)], pp. 81-90.

Dunin Janusz, Oktadka i obwoluta w procesie komunikacji literackiej, „Nowe Książki” 1993, issue 1, pp. $70-71$.

Dunin Janusz, Oktadki, obwoluty $i$ wystawy ksiażek w komunikacji literackiej, [w:] Pismo zmienia świat. Czytanie. Lektura. Czytelnictwo, Wydawnictwo Naukowe PWN, Warszawa-Lódź 1998, pp. $98-105$.

Dunin Janusz, Papierowy bandyta. Książka kramarska i brukowa w Polsce, Łódź 1974.

Dwadzieścia lat literatury polskiej 1989-2009, part I-II: Życie literackie po 1989 roku, ed. Dariusz Nowacki, Krzysztof Uniłowski, Wydawnictwo Uniwersytetu Śląskiego, Katowice 2011.

Eco Umberto, Nowe środki masowego przekazu a przyszłość książki, trans. Adam Szymanowski, PIW, Warszawa 1996.

Hopfinger Maryla, Literatura i media po 1989 roku, Oficyna Naukowa, Warszawa 2010.

Jarecka Dorota, Obraz rozpisany na kartkach, „Gazeta Wyborcza” 2005, issue 149, p. 16

Judging a Book by Its Cover. Fans, Publishers, Designers, and the Marketing of Fiction, ed. Nicole Matthews, Nickianne Moody, Ashgate, Aldershot-Burlington, VT 2007.

Kroehl Heinz F., Buch und Umschlag im Test, Harenberg, Dortmund 1984. 
Krupa Bartłomiej, Poetyka powieści Marka Krajewskiego, „Podteksty” 2010, issue 4, on-line: http:// podteksty.amu.edu.pl/podteksty/?action=dynamic\&dzial=4\&id=158 [accessed on: 30.09 .2012 ].

Książki i ludzie. Rozmowy Barbary Lopieńskiej, Twój Styl, Warszawa 1998.

Lachman Magdalena, Gry z „tandeta” w prozie polskiej po 1989 roku, Universitas, Kraków 2004.

Lachman Magdalena, Mania wydawania, czyli o fenomenie „Lampy i Iskry Bożej”, [in:] „CZarne” oraz „Lampa i Iskra Boża”. Literatura na rynku idei, ed. Daniel Kalinowski, Akademia Pomorska w Słupsku, Słupsk 2010, pp. 97-124.

Lachman Magdalena, Nie(d)ocenione ustugi okladki, [in:] Stolice i prowincje kultury. Księga Jubileuszowa ofiarowana Profesor Alinie Kowalczykowej, ed. Jacek Brzozowski, Mirosław Skrzypczyk, Marek Stanisz, Wydawnictwo IBL, Warszawa 2012, pp. 566-584;

Lalak Mirosław, Słowo kuszące. O perswazyjności tekstu okazjonalnego w ksiażce literackiej, [in:] Rozgrywanie światów. Formy perswazji w kulturze wspótczesnej, ed. Inga Iwasiów, Jerzy Madejski, Wydawnictwo Uniwersytetu Szczecińskiego, Szczecin 1994, pp. 291-300.

Liberatura czyli literatura totalna. Teksty zebrane z lat 1999-2009, ed. Katarzyna Bazarnik, introduction Wojciech Kalaga, Korporacja Ha!art, Kraków 2010.

Literatura polska 1989-2009. Przewodnik, ed. Piotr Marecki, Korporacja Ha!art, Kraków 2010.

Loewe Iwona, Parateksty na oktadkach, [in:] tejże, Gatunki paratekstowe w komunikacji medialnej, Wydawnictwo Uniwersytetu Śląskiego, Katowice 2007, pp. 85-111.

Masiewicz Krzysztof [interview] - Polowanie na okładki i kluczowe sceny. Rozmowa z Krzysztofem Masiewiczem, [in:] Frąckiewicz Sebastian, Wyjście z getta. Rozmowy o kulturze komiksowej w Polsce, Stowarzyszenie 40000 Malarzy, Warszawa 2012, pp. 224-243.

Mizerka Anna, O publicznym wizerunku Manueli Gretkowskiej i estetyce kampu, "Podteksty" 2006 issue 1; on-line: http://podteksty.amu.edu.pl/podteksty/?action=dynamic\&nr=4\&dzial $=4 \&$ id $=109$ [accessed by 30.09 .2012 ].

Od Joyce'a do liberatury. Szkice o architeksturze słowa, ed. Katarzyna Bazarnik, Universitas, Kraków 2002.

Różycka Dorota, Autorzy i ich maski. O fotografiach pisarzy współczesnych, [w:] Teatr wielki, mniejszy $i$ codzienny, ed. Piotr Kowalski, Wydawnictwo Uniwersytetu Opolskiego, Opole 2002, p. 211-230.

Rychlewski Marcin, Suwaki, plakaty i inne atrakcje. Rzecz o oktadkach rockowych, "Kultura Popularna" 2003, issue 3, pp. 95-101 (abridged version of the text: Suwaki, plakaty i inne atrakcje. O okładkach rockowych, „Polonistyka” 2007, issue 1, pp. 45-50).

Rypson Piotr, Ksiązki i Strony. Polska ksiązka awangardowa i artystyczna w XX wieku, CSW, Warszawa 2000.

Rypson Piotr, Nie gęsi. Polskie projektowanie graficzne 1919-1949, Wydawnictwo Karakter, Kraków 2011.

Sekuła Anna Elżbieta, Okładka „Cosmopolitan”, „Kultura Współczesna” 2004, issue 4, pp. 11-15.

Shillingsburg Peter L., From Gutenberg to Google. Electronic Representation of Literary Texts, Cambridge University Press, Cambridge 2006.

Stowa narastaja powoli. Rozmowa z Jerzym Jarniewiczem, interviewed by Marzena Bomanowska, Piotr Wesołowski, "Gazeta Łódzka" [insert in "Gazeta Wyborcza"] 02.10.2003, p. 6.

Stownik literatury popularnej, ed. Tadeusz Żabski, $2^{\text {nd }}$ edition corrected and amended, Wydawnictwo Uniwersytetu Wrocławskiego, Wrocław 2006.

Stępień Tomasz, Tekst okładki, [in:] Dzieto literackie i ksiązka w kulturze. Studia i szkice ofiarowane profesor Renacie Ocieczek w czterdziestolecie pracy naukowej i dydaktycznej, ed. Ireneusz Opacki in coopration with Bożena Mazurkowa, Wydawnictwo Uniwersytetu Śląskiego, Katowice 2002, pp. 502-510.

Szczęśniak Katarzyna, Okładka i obwoluta jako przedmiot badań interdyscyplinarnych, "Toruńskie Studia Bibliologiczne" 2011, issue 2, pp. 29-41. 
Szyłak Jerzy, Okładki i odbiorcy. Komiks jako ksiązka, [in:] Poetyka komiksu. Warstwa ikoniczna i językowa, słowo/obraz terytoria, Gdańsk 2000, pp. 154-173.

Tekst-tura. Wokót nowych form tekstu literackiego i tekstu jako dzieła sztuki, ed. Małgorzata Dawidek Gryglicka, Korporacja Ha!art, Kraków 2005.

Tierling Ewa, Czytajmy Rodziewiczównę! O perswazyjności okładki, [in:] Rozgrywanie światów. Formy perswazji w kulturze współczesnej, ed. Inga Iwasiów, Jerzy Madejski, Wydawnictwo Uniwersytetu Szczecińskiego, Szczecin 1994, pp. 273-289.

Trzynadlowski Jacek, Autor, dzieło, wydawca, $2^{\text {nd }}$ edition amended, Ossolineum, Wrocław 1988, pp. 171-173.

Tysiac polskich okładek. One Thousand Polish Book Covers, selection by Daniel Mizieliński, Aleksandra Mizielińska, Stowarzyszenie 40000 Malarzy, Warszawa 2010.

Ugrešić Dubravka, Czytanie wzbronione, trans. Dorota Jovanka Cirlić, Świat Literacki, Izabelin 2004.

Uniłowski Krzysztof, Koloniści i koczownicy. O najnowszej prozie i krytyce literackiej, Universitas, Kraków 2002.

Varga Krzysztof, Melancholia okładek, czyli spieszmy się zbierać książki, "Duży Format” [supplement to "Gazeta Wyborcza" 2011, issue 109] 2011, issue 18, p. 19.

Wieczorek Marcin, ,, bruLion”. Instrukcja obstugi, Korporacja Ha!art, Kraków 2005.

Wolny-Hamkało Agnieszka, Zrób mi dobrze, czyli krótki tekst o pisaniu blurbów, portliteracki.pl, 15.03.2007, http://portliteracki.pl/przystan/teksty/zrob-mi-dobrze-czyli-krotki-tekst-o-pisaniu -blurbow/ [accessed on: 30.03.2016].

Urbanowicz Janusz A., Okladki: blurb, blurb, “Esensja” 2001, issue 7 (on-line: http://www.esensja. pl/magazyn/2001/07/iso/13_23.html [accessed on: 30.09.2012]).

Węgrzyniak Anna, Pomnik z czarnego marmuru. O książce Tadeusza Różewicza „,Matka odchodzi”, [in:] Dzieło literackie i ksiązka w kulturze. Studia i szkice ofiarowane profesor Renacie Ocieczek w czterdziestolecie pracy naukowej i dydaktycznej, ed. Ireneusz Opacki in cooperation with Bożena Mazurkowa, Wydawnictwo Uniwersytetu Śląskiego, Katowice 2002, pp. 511-520.

\section{Book cover inventory (in the latest literature)}

\section{(Summary)}

The change in the context of the functioning of literature since 1989 and the transformations contemporary literary life has been subject to due to various reasons have resulted in the need to add a literary science reflection on the latest or not yet fully used up thematic areas. One of the notions worth raising, which increasingly seizes the attention of researchers as well as literary critics, is the issue of the book cover considered as a significant element of the work and its non-neutral identifier. The article defines what kind of a source of knowledge on the work and its author the book cover has become; how writers themselves define themselves through it; how they use it to characterise or present themselves or clarify the strategies they choose; how literature functions and copes while being subjected to the influence of mass culture and various marketing actions or the influence of celebrity-based and (self)promotionally focussed pop culture.

Key words: cover, the latest literature, literary life since 1989 